\title{
Response of vital functions, Apgar and cortisol in the prognosis of vigor against neonatal factors of lambs ${ }^{1}$
}

\author{
Glaucia B. Fagundes ${ }^{2 *}$ (D), Dayana Maria Nascimento ${ }^{3}$, Marcela R. Santiago ${ }^{2}$, \\ Camila A. Neves ${ }^{4}$, Cleidson M.G. Silva ${ }^{5}$, Eunice Oba ${ }^{6}$, Mônica Arrivabene ${ }^{7}$ \\ and Tânia V. Cavalcante ${ }^{7}$
}

\begin{abstract}
Fagundes G.B., Nascimento D.M., Santiago M.R., Neves C.A., Silva C.M.G., Oba E., Arrivabene M. \& Cavalcante T.V. 2019. Response of vital functions, Apgar and cortisol in the prognosis of vigor against neonatal factors of lambs. Pesquisa Veterinária Brasileira 39(2):155-162. Universidade Federal do Piauí, Campus Professora Cinobelina Elvas, Rod. Municipal Bom Jesus Viana Km 1, Planalto Horizonte, Bom Jesus, PI 64900-000, Brazil. E-mail: glauciatuante@hotmail.com

The management of lambs during the neonatal period has been studied in several researches due to the vital and hormonal organic adaptations undergone by the calf after birth. However, gender, number of pups and type of delivery play an important role in understanding neonatal vigor. The study of these groups with the monitoring of clinical evolution and cortisol metabolism becomes an indispensable subsidy for a better understanding of this neonatal phase, aiming to minimize the losses generated. The objective of this study was to evaluate the influence of gender, number of pups and type of delivery in the prognosis of neonatal vigor of lambs through clinical and cortisol diagnosis. Thirty crossbred Santa Inês lambs with Dorper in the neonatal phase were divided into three groups: male and female, number of pups (single and twin) and type of delivery (eutocic and dystocic). In each group, clinical evaluation of heart and respiratory rate, rectal temperature, Apgar score and weight were performed; and with the exception of cortisol, all evaluations were performed at fifteen and sixty minutes, as well as at twelve and twenty-four hours. In addition, blood samples were collected for cortisol dosage obtained in two moments at fifteen and sixty minutes using the radioimmunoassay technique. Among the three experimental groups related to lamb vigor, the heart rate was the only one that showed lower mean values $(\mathrm{P}<0.05)$ at twenty-four hours in the male group $90.00 \pm 20.20 \mathrm{bpm}$, twins $96.44 \pm 20.02 \mathrm{bpm}$ and eutocic $93.25 \pm 18.11 \mathrm{bpm}$. Differences in respiratory rate values were observed in the eutocic group $(64.00 \pm 14.75 \mathrm{mpm})$ at twenty-four hours. In the group of males there was a significant reduction in body temperature during the evaluation moments $(\mathrm{P}<0.05)$. Lambs from the group of twins showed lower body weight during the evaluations. At both times the analysis of serum cortisol was less than at sixty minutes. It was concluded that soon after the birth
\end{abstract}

\footnotetext{
${ }^{1}$ Received on July 24, 2018.

Accepted for publication on August 22, 2018.

${ }^{2}$ Post-Graduate Program in Animal Science, Universidade Federal do Piauí (UFPI), Campus Professora Cinobelina Elvas, Rod. Municipal Bom Jesus-Viana Km 1, Planalto Horizonte, Bom Jesus, PI 64900-000, Brazil. E-mail: m.ribeirosantiago@hotmail.com; *Corresponding author: glauciatuante@hotmail.com

${ }^{3}$ Residency in Multiprofessional Health Area, Veterinary Medicine, Animal Reproduction, Hospital Veterinário Universitário, Centro de Ciências Agrárias (CCA), Universidade Federal do Piauí (UFPI), Avenida Universitária s/n, Bairro Ininga, Teresina, PI 64049-550, Brazil. E-mail: dayana.vet@hotmail.com

${ }^{4}$ Post-Graduate Program in Animal Science, Centro de Ciências Agrárias (CCA), Universidade Federal do Piauí (UFPI), Avenida Universitária s/n, Bairro Ininga, Teresina, PI 64049-550. E-mail: milarrivabene@hotmail.com
}

\footnotetext{
${ }^{5}$ Universidade Federal do Piauí (UFPI), Campus Professora Cinobelina Elvas, Rod. Municipal Bom Jesus Viana Km 1, Planalto Horizonte, Bom Jesus, PI 64900-000. E-mail: gomesvet@hotmail.com

${ }^{6}$ Departamento de Reprodução Animal e Radiologia Veterinária, Faculdade de Medicina Veterinária e Zootecnia, Universidade Estadual Paulista (Unesp), Rua Adolfo Pardini s/n, Jardim Paraíso, Botucatu, SP 18610-250, Brazil. E-mail: euniceoba@fmvz.unesp.br

${ }^{7}$ Departamento de Clínica e Cirurgia Veterinária, Centro de Ciências Agrárias (CCA), Universidade Federal do Piauí (UFPI), Campus Universitário Ministro Petrônio Portella (CUMPP), Avenida Universitária s/n, Bairro Ininga, Teresina, PI 64049-550. E-mails: arrivabenevet@hotmail.com, cavalcante.tv@gmail.com
} 
there were marked changes in the physiological parameters and weight of Santa Inês lambs, but were not enough to cause negative effects on the vigor of the neonates, indicating the occurrence of effective neonatal adaptation capacity in this species.

INDEX TERMS: Vital functions, Apgar score, cortisol, prognosis of vigor, neonatal, lambs, newborns, type of birth, sex, birth, time period moments.

RESUMO.- [Resposta das funções vitais, de Apgar e cortisol no prognóstico de vigor frente a fatores neonatais de cordeiros.] O manejo dos cordeiros durante o período neonatal tem sido objeto de estudo em diversas pesquisas devido às adaptações orgânicas vitais e hormonais sofridas pela cria após o parto. Todavia, o gênero, número de filhotes e o tipo de parto parecem desempenhar um papel importante para melhor compreensão do vigor neonatal. Além disso, o estudo destes grupos com o acompanhamento da evolução clínica e do metabolismo do cortisol torna-se um subsidio indispensável para melhor compreensão dessa fase neonatal, visando minimizar as perdas geradas. Dessa forma, o objetivo do presente trabalho foi avaliar a influência do gênero, número de filhotes e tipo de parto na apresentação do vigor neonatal dos cordeiros através do diagnostico clinico e de cortisol. Foram utilizados trinta cordeiros mestiços da raça Santa Inês com Dorper em fase neonatal divididos em três grupos: gênero (macho e fêmea), número de filhotes (único e gemelar) e tipo de parto (eutócico e distócico). Em cada grupo, foi realizada a avaliação clínica da frequência cardíaca e respiratória, temperatura retal, escore Apgar e peso; e com a exceção do cortisol, todas as avaliações foram realizadas aos quinze e sessenta minutos, como também às doze e vinte e quatro horas. Adicionalmente, procedeu-se com a coleta de amostras de sangue total para dosagem de cortisol obtida em dois momentos aos quinze e sessenta minutos através da técnica de radioimunoensaio. Dentre os três grupos experimentais relacionados com vigor dos cordeiros, a frequência cardíaca foi a única que evidenciou menores médias $(\mathrm{P}<0,05)$ às vinte $\mathrm{e}$ quatro horas no grupo dos machos $90,00 \pm 20,20 \mathrm{bpm}$, gêmeos $96,44 \pm 20,02 \mathrm{bpm}$ e eutócicos $93,25 \pm 18,11 \mathrm{bpm}$. Observou-se no grupo eutócico diferenças nos valores da frequência respiratória de $64,00 \pm 14,75 \mathrm{mpm}$ às vinte e quatro horas. No grupo dos machos houve redução significativa na temperatura corpórea durante os momentos de avaliação $(\mathrm{P}<0,05)$. Cordeiros do grupo de gêmeos demonstraram menor peso corpóreo durante as avaliações. Em ambos momentos a análise do cortisol sérico demonstrou se menor aos sessenta minutos. Pôde se concluir que logo após o parto ocorreram alterações marcantes nos parâmetros fisiológicos e peso de cordeiros Santa Inês, porém não foram suficientes para causar efeitos negativos sobre o vigor dos neonatos, indicando a ocorrência de efetiva capacidade de adaptação neonatal nesta espécie.

TERMOS DE INDEXAÇÃO: Funções vitais, Apgar escore, cortisol, prognóstico de vigor, neonatal, cordeiros, ovinos, recém-nascidos, aspectos fisiológicos.

\section{INTRODUCTION}

The number of lambs sold per sheep affects profitability favorably (Lôbo et al. 2011), mainly because the sale of lambs has increased in the last decades (Morel et al. 2008). The production of more lambs followed by greater mortality is unacceptable, both from the economic point of view and from the animal and veterinary standpoints (Nowak 1996, Everett-Hincks et al. 2005). At this stage it is convenient to resort to clinical intervention, to minimize or avoid future negative consequences for the health and vigor of these animals. To end this financial loss and minimize mortality, veterinarians carry on specific resuscitation procedures and supportive care (Ravary-Plumioën 2009). To achieve high performance levels in lamb breeding, attention to the lamb from birth (Kenyon \& Blair 2014) up to its first 24 hours of life is needed, as this is the most important period for the newborn pup.

The newborn's adaptive development period is considered critical and crucial, since fast physiological adjustments are needed that are important for the lamb's health, which is intrinsically related to the organic immaturity of compensatory and regulatory multisystems, especially due to the animal's new status of vulnerability vis-à-vis the environment, plus the difficulty of rendering clinical assistance, especially under extensive management conditions. This is a period seen as critical to newborn pups, as profound physiological, nutritional and environmental adjustments are required, due to the replacement of the uterine medium by the extrauterine environment. This period is dramatic and dangerous, since the immaturity of organic systems may be decisive for organ failure or dysfunction leading to death, a situation that calls for great care in the identification of risk factors.

The general death rate quoted in the literature about Santa Inês lambs is of 15.1\% (Girão et al. 1998), and constitutes a challenge for the production of small ruminants. Although reports of lamb mortality rates at the fetal-neonatal transition stage in the Northeast are scarce, it is believed that its economic impact in the region is high and, thus, a deficient or absent clinical assistance/support may lead to an increase in perinatal mortality, limiting the production and survival of lambs. At birth and in subsequent days of extrauterine life, thermoregulatory, cardiovascular, respiratory and homeostatic mechanisms complete the maturation of the newborn (Chniter et al. 2013). This adaptive process depends on the activation of the hypothalamic-pituitary-adrenal axis, mediated by cortisol, which is a strong metabolic stimulator (Wood 1999).

The little research aimed at investigating the vital parameters contemplates lambs at the adult stage, and there has been no advancement in the neonatology of lambs at any particular age bracket. This emphatically justifies this research, which could be usually employed in the clinical routine and, along with the evaluations associated with the Apgar score and the determination of weight, would allow for an early diagnosis of low neonatal adaptation capacity, with positive implications for the newborn's health. The use of neonatal vitality scores can guide the choice of suitable therapeutic measures to 
ensure and increase the newborns' survival (Lourenço \& Machado 2013).

This study aimed to evaluate the influence of gender, number of pups and type of delivery in the presentation of the neonatal vigor of lambs through clinical and cortisol diagnosis.

\section{MATERIALS AND METHODS}

The experiment was carried out at Fazenda Santa Tereza, in the village of Barra da Ininga, located $100 \mathrm{~km}$ from the county of Matões, in the state of Maranhão (MA), in the period between December 2016 and May 2017. The farm's geographical coordinates are: latitude $5^{\circ} 28^{\prime} 47^{\prime \prime} \mathrm{S}$, longitude $43^{\circ} 0^{\prime} 95^{\prime \prime} \mathrm{W}$ and altitude $102 \mathrm{~m}$. The experiment was approved by the Ethics Committee under protocol no. 034/2015.

Thirty sheep of the Santa Inês breed aged from 1.5 to 4 years were used, after being dewormed and vaccinated against enterotoxaemia. The animals were submitted to a hormonal estrus synchronization protocol. Intravaginal sponges containing medroxyprogesterone acetate $^{1}$ were inserted at a random phase of the estrus cycle (day 0 ) and kept there for 14 days, after which the sponges were removed and 300 international units (IU) of equine chorionic gonadotrophic ${ }^{2}$ (eCG) were administered intramuscularly. The type of conception adopted was natural impregnation using four $(n=4)$ Dorper sheep. After 45 days of the treatment and impregnation, the study proceeded with 19 pregnant females, diagnosed by ultrasound (ALOKA model).

The pregnancy time of females was between 146 and 157 days. During the whole pregnancy period the sheep were handled extensively during the day in pastures with Tanzania grass (Panicum maximum cv. Tanzania) and the native pasture typical of the region, gathered in the afternoon and fed a ration concentrate containing soy meal, corn, urea, salt and water at will. Close to delivery of the pups the sheep were handled in the pen, remaining under supervision of the researcher at the place of parturition. After birth, time was allowed for removal of fetal wraps and cleansing of the airways as well as for the establishment of the postpartum maternal-fetal bond. All lambs had their navels cured with a $10 \%$ iodine solution and were breast-fed by their mothers, avoiding further stress which would result from separation.

After birth, the newborn $(n=30)$ were broken down into groups according to criteria checked at birth, such as gender (male and female), number of pups (one or twins) and type of delivery (euthymic and dystocic) evaluated at different moments. In the pen, each group of newborns was evaluated using the heart and respiratory rates, rectal temperature, Apgar score and weight parameters, checked at M 15 and M 60min and at M 12 and M 24 hours. The blood samplings for ascertainment of the cortisol hormone took place at M 15 and M 60min. A chronometer was used in the neonatal evaluation for 60 -second measurements to check heart rate (HR) in beats per minute (bpm) using a stethoscope, and respiratory frequency (RF) was checked and measured in movements per minute ( $\mathrm{mpm}$ ) through the observation of movements of the thorax and abdomen (flank). A digital clinical thermometer was inserted in the rectum until the stabilization of rectal temperature in degrees "Celsius" $\left({ }^{\circ} \mathrm{C}\right)$ was reached. Weighing $(\mathrm{kg})$ was done using a cloth ribbon to suspend the lamb from the portable electronic balance using a hook.

To obtain the Apgar score modified for sheep, points were attributed to the following items: evaluation of head movement with cold water, response to the eye-palpebral and interdigital reflex, breathing type and mucosal staining, with scores going from zero to

\footnotetext{
1 Progespon $^{\circledR}$, Syntex. Buenos Aires, Argentina.

2 Novormon $^{\circledR}$, Syntex. Buenos Aires, Argentina.
}

two. Each item was classified by assigning 0, 1 or 2 points, and the final result (the sum from 0-10) was considered as the Apgar score.

Scoring is interpreted as follows: seven to eight points represent good vitality; four to six characterize average vitality; and zero to three is considered a low-vitality score (depressed).

The lambs' jugular veins were punctured at M 15min and, later, at $\mathrm{M} 60 \mathrm{~min}$, to obtain the serum and for the determination of cortisol using the radioimmunoassay technique. This was done at the Laboratory of Endocrinology of the Department of Animal Reproduction and Veterinary Radiology (Laboratório de Endocrinologia do Departamento de Reprodução Animal e Radiologia Veterinária) of Faculdade de Medicina Veterinária e Zootecnia of Universidade Estadual Paulista (Unesp/SP) of the Botucatu Campus, using an IM1841 solid cortisol commercial kit from Beckman Coulter, following the manufacturer's recommendations, and the reading was carried out by radioimmunoassay gamma counter (Perkin Elmer 1470, automatic gamma counter).

To minimize individual variation in all evaluations, animals were kept preferably in a stationary position and in repose, and measurements were carried out by a single person at a station and by a single examiner.

Data were tested for normality and homogeneity of variances using the Shapiro-Wilk and Bartlett tests, respectively; afterwards, the figures were subjected to analysis of variance with time-repeated measurements (ANOVA). Parameters which showed an abnormal (parametric) distribution were compared at the points in time in each group using the Tukey test, and between groups at each point using the t-Student test, at the 5\% probability level, respectively.

As for the parameters which did not present a normal distribution (non-parametric), these were compared at the points in each group using the Kruskal-Wallis test, and between groups at each point using the Mann \& Whitney test at the 5\% probability level, respectively. The mucosal staining and Apgar score which showed non-parametric distribution were compared between groups at each point in time (moment, M) using Fisher's exact test. The cortisol concentrations were evaluated at 15 and 60 minutes after delivery, and compared using the t-Student test at the $5 \%$ probability level.

\section{RESULTS AND DISCUSSION}

All lambs presented a significant drop $(\mathrm{P}<0.05)$ in their heart rates (HR) at the points in time evaluated in each group according to gender, number of pups and types of delivery (Table 1). This fact was also evidenced by (Piccione et al. 2007) in lambs analyzed up to 30 days after birth; the existence of an inversely proportional ratio between age and heart rate should also be noted. The values found for these groups contrast with the reference values set for the species reported by (Bovino et al. 2014), who observed increases in the animals' HR in the moments mentioned, between $175 \pm 33 \mathrm{bpm}$ and $189 \pm 20 \mathrm{bpm}$, at 15 minutes and 24 hours, respectively. Compared to that of adult sheep, the heart rate of newborns is rapid and relatively unstable (Koether et al. 2016); it is under the control of the autonomic system, which action derives only from the sympathetic system (Ulian et al. 2014).

As for the gender (male and female), the heart rate was significantly lower $(\mathrm{P}<0.05)$ in males (Table 1$)$. This contrasted with the reports by (Koether et al. 2016), who did not observe influence of gender on the electrocardiogram of lambs of the Bergamácia breed. However, an increase was reported due to physical maturation, especially at 24 hours; this increase shows that this distinct method can interfere in heart rate 
Table 1. Averages $(\bar{x})$ and standard deviations (S) of heart rate (HR) values in mixed-race lambs evaluated as a function of gender, number of pups and types of delivery. Matões/MA, 2017

\begin{tabular}{|c|c|c|c|c|c|}
\hline Variable & Moments & $\mathrm{n}$ & $\bar{x} \pm S$ & $\mathrm{n}$ & $\bar{x} \pm S$ \\
\hline & & \multicolumn{4}{|c|}{ Gender } \\
\hline \multirow{17}{*}{ HR (bpm) } & & & Male & & Female \\
\hline & M 15min & 14 & $129.55 \pm 15.42 \mathrm{aA}$ & 14 & $139.43 \pm 21.22 \mathrm{aA}$ \\
\hline & M 60min & 14 & $112.86 \pm 21.06 \mathrm{abA}$ & 14 & $123.54 \pm 13.77 \mathrm{abA}$ \\
\hline & M 12 hours & 14 & $95.65 \pm 16.47 \mathrm{bcA}$ & 14 & $108.19 \pm 21.12 \mathrm{bA}$ \\
\hline & M 24 hours & 14 & $90.00 \pm 20.20 \mathrm{cB}$ & 14 & $108.64 \pm 17.58 \mathrm{bA}$ \\
\hline & & \multicolumn{4}{|c|}{ No. of pups } \\
\hline & & $\mathrm{n}$ & Single & $\mathrm{n}$ & Twins \\
\hline & M 15min & 9 & $140.00 \pm 22.45 \mathrm{aA}$ & 19 & $131.88 \pm 16.98 \mathrm{aA}$ \\
\hline & M 60min & 9 & $131.11 \pm 12.29 \mathrm{aA}$ & 19 & $112.08 \pm 17.65 b B$ \\
\hline & M 12 hours & 9 & $106.67 \pm 16.25 \mathrm{bA}$ & 19 & $99.67 \pm 21.10 \mathrm{bA}$ \\
\hline & M 24 hours & 9 & $105.33 \pm 22.54 \mathrm{bA}$ & 19 & $96.44 \pm 20.02 \mathrm{bA}$ \\
\hline & & \multicolumn{4}{|c|}{ Type of delivery } \\
\hline & & $\mathrm{n}$ & Euthymic & $\mathrm{n}$ & Dystocic \\
\hline & M 15min & 16 & $129.00 \pm 19.79 \mathrm{aA}$ & 19 & $141.81 \pm 15.45 \mathrm{aA}$ \\
\hline & M 60min & 16 & $116.25 \pm 16.30 \mathrm{abA}$ & 19 & $120.79 \pm 21.11 b A$ \\
\hline & M 12 hours & 16 & $103.50 \pm 23.64 \mathrm{bcA}$ & 19 & $99.82 \pm 13.33 \mathrm{cA}$ \\
\hline & M 24 hours & 16 & $93.25 \pm 18.11 \mathrm{cA}$ & 19 & $107.41 \pm 22.28 \mathrm{bcA}$ \\
\hline
\end{tabular}

$\overline{\mathrm{aABbc}}$ Averages followed by different small letters in the same column differ between themselves by the Tukey test; averages followed by different capital letters in the same column differ between themselves by the t-Student test, respectively, at the $5 \%$ probability level.

results. Comparing heart rate values (Table 1) in the group classified by number of pups (single and twin), a difference was found only at 60 minutes, with a lower heart frequency in twin pups. Giannetto et al. (2017) observed greater HR values in twins due to the smaller heart size of the Comisana lambs. This has not been demonstrated in the present study, but the differences in breed and locality may have contributed to the increase in heart rates.

However, analyzing the group classified according to type of delivery (euthymic and dystocic) compared at each point in time, no significant difference can be observed in heart rate values (Table 1). Investigating the euthymic and dystocic types of delivery in calves, Gasparelli et al. (2009) observed a significant drop in HR at 24 hours, with average values of $132.20 \pm 18.74$ and $116.72 \pm 17.68 \mathrm{bpm}$, respectively. According to the authors, due to the action of catecholamines derived from the stress of delivery, there is an increase in heart rate at this stage which is physiological, followed by a gradual drop in HR over time. These results were higher than those reported in the present study, as a consequence of the species evaluated.

There was no significant difference in heart rate (HR) related to gender, number of pups and types of delivery at each point evaluated (Table 2). However, there was a statistical difference at the points in the case of lambs born in euthymic deliveries, in which there was a decrease along the first 24 hours $(64 \pm 14.65 \mathrm{mpm})$. In the present study the HR of lambs recorded at 24 hours was below the reference values described by Bovino et al. (2014), who reported an increase in the HR of mixed-race Suffolk/Texel lambs, which averaged $75 \pm 18 \mathrm{mpm}$ at that moment. It is likely that the differences between lamb breeds have interfered in the $\mathrm{HR}$ results. The irregular activity of the respiratory system in the neonatal period was reported by Piccione et al. (2007), and can be related to the fact that the adaptation of the lambs' respiratory system is different in the two types of delivery, with direct implications for the desirable post-delivery vigor. Hilaire \& Duron (1999) and Vestweber \& Rieß (1997) report the occurrence of alternate states of bradipnea and tachypnea until eupnea sets in, a period in which breathing frequency is at first irregular. Linke et al. (2013) emphasized the need for a minimum period of 14 days for the pulmonary units to be integrated into the gas exchange.

As for rectal temperature (RT), the study found that there were significant differences only between genders at 24 hours after birth and in the group classified according to the number of pups (single and twin) at each point in time (Table 3), with rectal temperature being lower in twins. There was no significant difference between the types of delivery in the first 24 hours of life. It deserves notice that the RT kept constant and within a very narrow range $\left(38-39^{\circ} \mathrm{C}\right)$ at those points. Ball et al. (2010) proposed normothermic reference temperatures of around $38-39^{\circ} \mathrm{C}$ for neonates of the sheep species. These results support the performance of sheep in relation to the homeostasis mechanism (Piccione et al. 2007), which requires for the most part changes in the energy metabolism (Greenwood et al. 2002), achieved through the $17 \%$ increase in the generation of heat (Dwyer et al. 2016) for the guarantee of vigor (Matheson et al. 2012) directed to the pup's search for position, search and suck of udder (Abdul-Rahman \& Bernard 2017) and post-birth survival (Dwyer et al. 2005). Thus, the behavioral development of neonates may be related to their vigor in the ability to achieve thermoregulation.

In the analysis of the body weight of lambs, significant differences were observed only in the group classified 
Table 2. Averages $(\bar{x})$ and standard deviations (S) of respiratory frequency (RF) values in mixed-race lambs evaluated as a function of gender, number of pups and types of delivery. Matões/MA, 2017

\begin{tabular}{|c|c|c|c|c|c|}
\hline Variable & Moments & $\mathrm{n}$ & $\bar{x} \pm S$ & $\mathrm{n}$ & $\bar{x} \pm S$ \\
\hline & & \multicolumn{4}{|c|}{ Gender } \\
\hline & & \multicolumn{3}{|c|}{ Male } & Female \\
\hline & M 15min & 14 & $79.43 \pm 15.20$ & 14 & $81.14 \pm 16.93$ \\
\hline & M 60min & 14 & $67.14 \pm 13.69$ & 14 & $74.57 \pm 13.46$ \\
\hline & M 12 hours & 14 & $65.14 \pm 19.93$ & 14 & $74.86 \pm 16.56$ \\
\hline & M 24 hours & 14 & $66.29 \pm 23.57$ & 14 & $74.29 \pm 19.00$ \\
\hline \multirow{12}{*}{$\mathrm{RF}$ (mpm) } & & \multicolumn{4}{|c|}{ No. of pups } \\
\hline & & $\mathrm{n}$ & Single & $\mathrm{n}$ & Twins \\
\hline & M 15min & 9 & $82.22 \pm 20.41$ & 19 & $79.37 \pm 13.68$ \\
\hline & M 60min & 9 & $71.11 \pm 13.97$ & 19 & $70.74 \pm 14.18$ \\
\hline & M 12 hours & 9 & $74.22 \pm 19.30$ & 19 & $68.00 \pm 18.52$ \\
\hline & M 24 hours & 9 & $76.44 \pm 20.04$ & 19 & $64.37 \pm 21.92$ \\
\hline & & \multicolumn{4}{|c|}{ Type of delivery } \\
\hline & & $\mathrm{n}$ & Euthymic & $\mathrm{n}$ & Dystocic \\
\hline & M 15min & 16 & $81.25 \pm 18.86 \mathrm{aA}$ & 12 & $79.00 \pm 11.20 \mathrm{aA}$ \\
\hline & M 60min & 16 & $73.25 \pm 15.44 \mathrm{abA}$ & 12 & $67.67 \pm 11.24 \mathrm{aA}$ \\
\hline & M 12 hours & 16 & $69.22 \pm 17.86 \mathrm{abA}$ & 12 & $71.33 \pm 20.38 \mathrm{aA}$ \\
\hline & M 24 hours & 16 & $64.00 \pm 14.75 \mathrm{bA}$ & 12 & $78.67 \pm 26.33 \mathrm{aA}$ \\
\hline
\end{tabular}

$\mathrm{mpm}=$ Movements per minute; ${ }^{\mathrm{aAb}}$ averages followed by small letters differ between themselves in the column by the Tukey test; averages followed by capital letters differ between themselves in the line by the t-Student test, at the $5 \%$ probability level.

Table 3. Averages $(\bar{x})$ and standard deviations (S) of rectal temperature (RT) values in mixed-race lambs evaluated as a function of gender, number of pups and types of delivery. Matões/MA, 2017

\begin{tabular}{|c|c|c|c|c|c|}
\hline Variable & Moments & $\mathrm{n}$ & $\bar{x} \pm S$ & $\mathrm{n}$ & $\bar{x} \pm S$ \\
\hline \multicolumn{6}{|c|}{ Gender } \\
\hline \multirow{12}{*}{$\mathrm{RT}\left({ }^{\circ} \mathrm{C}\right)$} & & & Male & & Female \\
\hline & M 15min & 14 & $38.64 \pm 0.71 \mathrm{aA}$ & 14 & $39.07 \pm 0.71 \mathrm{aA}$ \\
\hline & M 60min & 14 & $38.76 \pm 0.68 \mathrm{aA}$ & 14 & $39.04 \pm 0.56 \mathrm{aA}$ \\
\hline & M 12 hours & 14 & $38.99 \pm 0.35 \mathrm{aA}$ & 14 & $39.01 \pm 0.43 \mathrm{aA}$ \\
\hline & M 24 hours & 14 & $38.97 \pm 0.40 \mathrm{aB}$ & 14 & $39.36 \pm 0.32 \mathrm{aA}$ \\
\hline & M 15min & 9 & $39.32 \pm 0.24 \mathrm{aA}$ & 19 & $38.63 \pm 0.71 \mathrm{aB}$ \\
\hline & M 60min & 9 & $39.26 \pm 0.30 \mathrm{aA}$ & 19 & $38.73 \pm 0.56 \mathrm{aB}$ \\
\hline & M 12 hours & 9 & $39.23 \pm 0.22 \mathrm{aA}$ & 19 & $38.88 \pm 0.43 \mathrm{aB}$ \\
\hline & M 24 hours & 9 & $39.41 \pm 0.23 \mathrm{aA}$ & 19 & $39.05 \pm 0.32 \mathrm{aB}$ \\
\hline & & \multicolumn{4}{|c|}{ Type of delivery } \\
\hline & M 12 hours & 16 & $38.97 \pm 0.34$ & 12 & $39.03 \pm 0.45$ \\
\hline & M 24 hours & 16 & $39.13 \pm 0.38$ & 12 & $39.22 \pm 0.45$ \\
\hline
\end{tabular}

\footnotetext{
$\overline{\mathrm{AaB}}$ Averages followed by small letters differ between themselves in the column by the Kruskal-Wallis test; averages followed by capital letters differ between themselves in the line by the Mann \& Whitney test, at the 5\% probability level.
}

according to number of pups within each time period evaluated (Table 4). Lambs from twin deliveries had a lower weight average from 15 minutes to 24 hours after birth. In the present study it can be observed that there is no difference related to gender and type of delivery. These results contradict the values mentioned by Fazio et al. (2016), who did not find weight differences in the neonatal period in lambs born in twin deliveries $(3.20 \pm 0.13 \mathrm{~kg})$ and single deliveries (3.87 $\pm 0.34 \mathrm{~kg})$. Nobrega et al. (2005) mention that the temperatures of the semi-arid region favor the survival of pups, but the inadequate nutritional level of the matrixes in the final third of pregnancy contributes to the occurrence of starvation/hypothermia as a consequence of the low weight at birth. There are episodes of slower intrauterine growth rates 
in the maternal environment (Ergaz et al. 2005) as well as of smaller muscle mass (McCoard et al. 1997). Probably the way to minimize the occurrence of starvation/hypothermia and low weight in lambs is the nutrition of matrixes in the final stage of pregnancy.

When evaluating the Apgar score percentages of lambs, no significant difference was observed $(P>0.05)$ between the groups (gender, number of pups and type of delivery) at the time of evaluations, which shows the importance of an early determination of the Apgar score, immediately after birth, in all groups. The lambs were generally healthy and exhibited from good to moderate vitality, regardless of the groups analyzed.

A low Apgar score is particularly related to neonatal depression, which is caused by the various neonatal adjustments due to parturition, and may be similarly combined with other equally important factors such as gender, number of pups and type of delivery during the neonatal period. In view of these factors, a significant alteration in the Apgar score may take place in these pups, which should be analyzed to detect neonates with greater propensity to lower Apgar scores and requiring intervention for their reanimation. Thus, further studies need to be undertaken to gather knowledge on the occurrence of different Apgar score values associated with these factors during the neonatal period, especially at birth, as well as on the influence of the self-efficacy of the method in clinical situations requiring the emergency identification of high-risk lambs.

Among the 30 samples of serum used for cortisol dosage, only one was eliminated due to the fact that the result was zero at the points in time. As shown in Figure 1, cortisol levels were influenced by the moment $(\mathrm{P}<0.01)$, and a greater hormone concentration of $(457,76 \mu \mathrm{g} / \mathrm{ml})$ was found at M $15 \mathrm{~min}$, followed by a continuous drop of circulating cortisol at M $60 \mathrm{~min}$ $(178 \mu \mathrm{g} / \mathrm{ml})$. This was probably due to the fast metabolization of cortisol at the points in time (M 15 and 60min), the effective adaptation to stress and regulation of basal metabolism. According to Ferguson \& Warner (2008), cortisol is related to the adaptive metabolism of stress and to the basal level of metabolic regulation. The average cortisol serum concentration was higher than that found by Gasparelli et al. (2009) when these authors evaluated the level of the hormone in calves at birth, which was of $9.85 \pm .31 \mu \mathrm{g} / \mathrm{dL}$ and $9.02 \pm 2.83 \mu \mathrm{g} / \mathrm{dL}$, and at 24 hours, $3.45 \pm 2.11 \mu \mathrm{g} / \mathrm{dL}$ and $4.70 \pm 4.02 \mu \mathrm{g} / \mathrm{dL}$, for euthymic and dystocic deliveries respectively. These differences are due

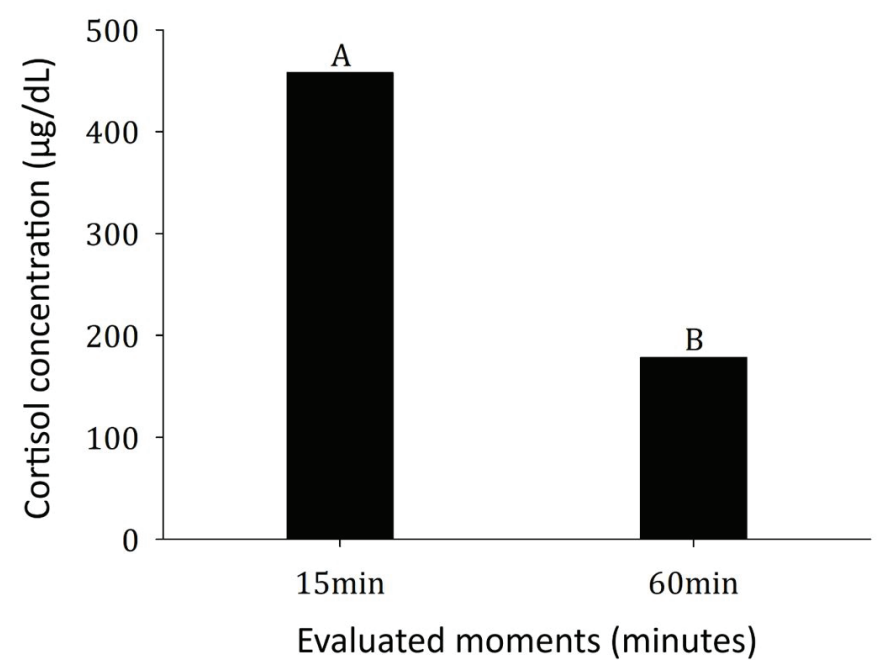

Fig.1. Cortisol levels $(\mu \mathrm{g} / \mathrm{dL})$ at each point in time:15 minutes and 60 minutes.

Table 4. Averages $(\bar{x})$ and standard deviations (S) of weight values in mixed-race lambs evaluated as a function of gender, number of pups and types of delivery. Matões/MA, 2017

\begin{tabular}{|c|c|c|c|c|c|}
\hline Variable & Moments & $\mathrm{n}$ & $\bar{x} \pm S$ & $\mathrm{n}$ & $\bar{x} \pm S$ \\
\hline \multicolumn{6}{|c|}{ Gender } \\
\hline & & & Male & & Female \\
\hline & M 15min & 14 & $2.85 \pm 0.84$ & 14 & $2.87 \pm 0.65$ \\
\hline & M 60min & 14 & $2.89 \pm 0.89$ & 14 & $2.88 \pm 0.68$ \\
\hline & M 12 hours & 14 & $2.81 \pm 0.92$ & 14 & $2.87 \pm 0.75$ \\
\hline & M 24 hours & 14 & $2.81 \pm 0.88$ & 14 & $2.88 \pm 0.78$ \\
\hline \multirow{12}{*}{ Weight (kg) } & & \multicolumn{4}{|c|}{ No. of pups } \\
\hline & & $\mathrm{n}$ & Single & $\mathrm{n}$ & Twins \\
\hline & M 15min & 9 & $3.37 \pm 0.76 \mathrm{aA}$ & 19 & $2.62 \pm 0.62 \mathrm{aB}$ \\
\hline & M 60min & 9 & $3.43 \pm 0.80 \mathrm{aA}$ & 19 & $2.62 \pm 0.64 \mathrm{aB}$ \\
\hline & M 12 hours & 9 & $3.42 \pm 0.83 a \mathrm{~A}$ & 19 & $2.57 \pm 0.69 \mathrm{aB}$ \\
\hline & M 24 hours & 9 & $3.40 \pm 0.85 a \mathrm{~A}$ & 19 & $2.59 \pm 0.67 \mathrm{aB}$ \\
\hline & & \multicolumn{4}{|c|}{ Type of delivery } \\
\hline & & $\mathrm{n}$ & Euthymic & $\mathrm{n}$ & Dystocic \\
\hline & M 15min & 16 & $2.71 \pm 0.64$ & 12 & $3.07 \pm 0.83$ \\
\hline & M 60min & 16 & $2.75 \pm 0.72$ & 12 & $3.06 \pm 0.86$ \\
\hline & M 12 hours & 16 & $2.71 \pm 0.75$ & 12 & $3.02 \pm 0.92$ \\
\hline & M 24 hours & 16 & $2.73 \pm 0.72$ & 12 & $3.01 \pm 0.94$ \\
\hline
\end{tabular}

\footnotetext{
${ }^{\mathrm{AaB}}$ Averages followed by small letters differ between themselves in the column by the Kruskal-Wallis test; averages followed by capital letters differ between themselves in the line by the Mann \& Whitney test, at the $5 \%$ probability level.
} 
to the species. However, the cortisol serum concentration followed the same trend at the points in time.

\section{CONCLUSIONS}

Marked changes in the physiological parameters and weight of Santa Inês lambs took place immediately after birth, but these changes were not sufficient to cause negative effects on the vigor of neonates, which indicates the effective capacity for neonate adaptation in this species.

These findings reinforce the need of further studies in this area for better understanding of neonatal vigor, which can serve as a diagnostic tool for the health management of newborn lambs, provided that they are adjusted for that stage.

Aknowledgements.- Our thanks to CAPES for the Master's scholarship, to PPGZOO/UFPI/CPCE, to Faculdade de Medicina Veterinária e Zootecnia of Universidade Estadual Paulista (Unesp), Botucatu Campus, for the partnership and for carrying out the hormone dosage measurements in its Laboratory, to the owner of Fazenda Santa Tereza and to the Veterinarian and Prof. Dr. Willams Costa Neves for the assignment of the animals.

Conflict of interest statement.- The authors declare no conflict of interest.

\section{REFERÊNCIAS}

Abdul-Rahman I.I. \& Bernard A. 2017. Vigour in West African dwarf kids within the first $24 \mathrm{~h}$ post-partum. Trop. Anim. Health Prod. 49(3):547-553. <http://dx.doi.org/10.1007/s11250-017-1226-7> <PMid:28110365>

Ball M.K., Hillman N.H., Kallapur S.G., Polglase G.R., Jobe A.H. \& Pillow J.J. 2010. Body temperature effects on lung injury in ventilated preterm lambs. Resuscitation 81(6):749-754. <http://dx.doi.org/10.1016/j. resuscitation.2009.12.007><PMid:20299144>

Bovino F., Camargo D.G.D., Araújo M.A.D., Costa F.D.P., Santos P.S.P.D., Mendes L.C.N., Peiró J.R. \& Feitosa F.L.F. 2014. Avaliação da vitalidade de cordeiros nascidos de partos eutócicos e cesarianas. Pesq. Vet. Bras. 34(Suppl.1):11-16. <http://dx.doi.org/10.1590/S0100-736X2014001300003>

Chniter M., Hammadi M., Khorchani T., Ben Sassi M., Ben Hamouda M. \& Nowak R. 2013. Aspects of neonatal physiology have an influence on lambs' early growth and survival in prolific D'man sheep. Small Rum. Res. 111(1/3):162170. <http://dx.doi.org/10.1016/j.smallrumres.2012.10.004>

Dwyer C.M., Calvert S.K., Farish M., Donbavand J. \& Pickup H.E. 2005. Breed, litter and parity effects on placental weight and placentome number, and consequences for the neonatal behaviour of the lamb. Theriogenology 63(4):1092-1110.<http://dx.doi.org/10.1016/j.theriogenology.2004.06.003> <PMid:15710196>

Dwyer C.M., Conington J., Corbiere F., Holmøy I.H., Muri K., Nowak R., Rooke J., Vipond J. \& Gautier J.M. 2016. Invited review: improving neonatal survival in small ruminants: science into practice. Animal 10(3):449-459. <http:// dx.doi.org/10.1017/S1751731115001974><PMid:26434788>

Ergaz Z., Avgil M. \& Ornoy A. 2005. Intrauterine growth restriction, etiology and consequences: what do we know about the human situation and experimental animal models? Reprod. Toxicol. 20(3):301-322. <http:// dx.doi.org/10.1016/j.reprotox.2005.04.007><PMid:15982850>

Everett-Hincks J.M., Lopez-Villalobos N., Blair H.T. \& Stafford K.J. 2005. The effect of ewe maternal behaviour score on lamb and litter survival. Livest. Prod. Sci. 93(1):51-61.<http://dx.doi.org/10.1016/j.livprodsci.2004.11.006>

Fazio F., Arfuso F., Giudice E., Giannetto C. \& Piccione G. 2016. Physiological differences between twin and single-born lambs and kids during the first month of life. Arch. Anim. Breed 59(2):201-207. <http://dx.doi. org/10.5194/aab-59-201-2016>
Ferguson D.M. \& Warner R.D. 2008. Have we underestimated the impact of pre-slaughter stress on meat quality in ruminants? Meat Sci. 80(1):12-19. <http://dx.doi.org/10.1016/j.meatsci.2008.05.004> <PMid:22063165>

Gasparelli E.R.F., Camargo D.G., Yanaka R., Mendes L.C.N., Peiró J.R., Bovino F., Perri S.H.V. \& Feitosa F.L.F. 2009. Avaliação física e dos níveis séricos de cortisol de bezerros neonatos da raça Nelore, nascidos de partos normais e auxiliados. Pesq. Vet. Bras. 29(10):823-828. <http://dx.doi.org/10.1590/ S0100-736X2009001000008>

Giannetto C., Arfuso F., Fazio F., Giudice E., Panzera M. \& Piccione G. 2017. Rhythmic function of body temperature, breathing and heart rates in newborn goats and sheep during the first hours of life. J. Vet. Behav. 18:2936. <http://dx.doi.org/10.1016/j.jveb.2016.12.002>

Girão R.N., Medeiros L.P. \& Girão E.S. 1998. Mortalidade de cordeiros da raça Santa Inês em um núcleo de melhoramento no estado do Piaui. Ciência Rural 28(4):641-645. <http://dx.doi.org/10.1590/S0103-84781998000400017>

Greenwood P.L., Hunt A.S., Slepetis R.M., Finnerty K.D., Alston C., Beermann D.H. \& Bell A.W. 2002. Effects of birth weight and postnatal nutrition on neonatal sheep: III. Regulation of energy metabolism. J. Anim. Sci. 80(11):28502861. <http://dx.doi.org/10.2527/2002.80112850x ><PMid:12462252>

Hilaire G. \& Duron B. 1999. Maturation of the mammalian respiratory system. Physiol. Rev. 79(2):325-360. <http://dx.doi.org/10.1152/ physrev.1999.79.2.325><PMid:10221983>

Kenyon P.R. \& Blair H.T. 2014. Foetal programming in sheep-effects on production. Small Rum. Res. 118(1-3):16-30. <http://dx.doi.org/10.1016/j. smallrumres.2013.12.021>

Koether K., Ulian C.M., Lourenço M.L., Gonçalves R.S., Sudano M.J., Cruz R.K., da Silva Branchini N., Alfonso A. \& Chiacchio S.B. 2016. The normal electrocardiograms in the conscious newborn lambs in neonatal period and its progression. BMC Physiol. 2016(16):1. <http://dx.doi.org/10.1186/ s12899-016-0020-5><PMid:26786197>

Linke B., Bostedt H. \& Richter A. 2013. Computer tomographic illustration of the development of the pulmonary function in bovine neonates until the twenty-first day postnatum. Vet. Med. Int. 2013:157960. <http://dx.doi. org/10.1155/2013/157960><PMid:24175112>

Lôbo R.N.B., Pereira I.D.C., Facó O. \& McManus C.M. 2011. Economic values for production traits of Morada Nova meat sheep in a pasture based production system in semi-arid Brazil. Small Rum. Res. 96(2/3):93-100. <http://dx.doi.org/10.1016/j.smallrumres.2011.01.009>

Lourenço M.L.G. \& Machado L.H.A. 2013. Características do período de transição fetal-neonatal e particularidades fisiológicas do neonato canino. Revta Bras. Reprod. Anim. 37:303-308.

Matheson S.M., Bünger L. \& Dwyer C.M. 2012. Genetic parameters for fitness and neonatal behavior traits in sheep. Behav. Genet. 42(6):899-911. <http:// dx.doi.org/10.1007/s10519-012-9562-x><PMid:23053733>

McCoard S.A., Peterson S.W., McNabb W.C., Harris P.M. \& McCutcheon S.N 1997. Maternal constraint influences muscle fibre development in fetal lambs. Reprod. Fertil. Dev. 9(7):675-681. <http://dx.doi.org/10.1071/ R97061> <PMid:9623486>

Morel P.C.H., Morris S.T. \& Kenyon P.R. 2008. Effect of birthweight on survival in triplet-born lambs. Aust. J. Exp. Agric. 48(7):984-987. <http://dx.doi. org/10.1071/EA07401>

Nóbrega Jr J.E.D., Riet-Correa F., Nóbrega R.S., Medeiros J.M.D., Vasconcelos J.S.D., Simões S.V.D. \& Tabosa I.M. 2005. Mortalidade perinatal de cordeiros no semi-árido da Paraíba. Pesq. Vet. Bras. 25(3):171-178. <http://dx.doi. org/10.1590/S0100-736X2005000300008>

Nowak R. 1996. Neonatal survival: contributions from behavioural studies in sheep. Appl. Anim. Behav. Sci. 49(1):61-72. <http://dx.doi.org/10.1016/01681591(95)00668-0>

Piccione G., Borruso M., Fazio F., Giannetto C. \& Caola G. 2007. Physiological parameters in lambs during the first 30 days postpartum. Small Rum. Res. 72(1):57-60. <http://dx.doi.org/10.1016/j.smallrumres.2006.04.002> 
Ravary-Plumioën B. 2009. Resuscitation procedures and life support of the newborn calf. Rev. Méd. Vét. 160:410-419.

Ulian C.M.V., Koether K., Lourenço M.L.G., Gonçalves R.S., Sudano M.J., Cruz R.K.S., Silva N.B. \& Chiacchio S.B. 2014. Physiological parameters in neonatal lambs of the bergamasca breed. Acta Scient. Vet. 42:1183.
Vestweber H. \& Rieß W. 1997. Highly efficient and stable organic light-emitting diodes. Synth. Met. 91(1/3):181-185. <http://dx.doi.org/10.1016/S03796779(97)04014-9>

Wood C.E. 1999. Control of parturition in ruminants. J. Reprod. Fertil. 54:115126. <PMid:10692849> 